\title{
PENINGKATAN DAYA SAING DODOL NANAS SI-JANK MELALUI STRATEGI PEMASARAN PRODUK
}

\author{
Susilawati ${ }^{1)}$, Sunardi $^{2)}$ \\ 1)Politeknik Negeri Sambas, Jl. Raya Sejangkung, Sambas-Kalbar, shecerahceria@gmail.com \\ ${ }^{2}$ Politeknik Negeri Sambas, Jl. Raya Sejangkung, Sambas-Kalbar, sunardi_adi@yahoo.co.id
}

\begin{abstract}
Abstrak : Dodol merupakan salah satu jenis makanan ringan tradisional yang banyak ditemukan pada berbagai daerah yang ada di Indonesia. Salah satu usaha UKM di Desa Sijang Kecamatan Galing Kabupaten Sambas yang melakukan pengolahan nanas menjadi dodol nanas adalah UKM Mawar Merah dengan merek dodol nanas Si-Jank. Mengingat usaha produksi dodol nanas Si-Jank dari UKM Mawar Merah ini baru dilakukan sejak tahun 2018, maka usaha pengolahan dodol nanas ini memberikan peluang yang cerah untuk dikembangkan. Namun, hasil penjualan dodol nanas Si-Jank belum maksimal, sehingga belum tercapainya target penjualan maupun keuntungan yang diharapkan, serta menurunnya penjualan selama pandemic Covid-19. Pemasaran dodol nanas Si-Jank yang tepat sangat berperan penting guna keberhasilan usaha ini. Pemasaran dodol nanas Si-Jank ini dipengaruhi oleh faktor-faktor internal (kekuatan dan kelemahan) dan eksternal (peluang dan ancaman) serta adanya strategi yang tepat pada pemasaran dodol nanas Si-Jank. Oleh karena itu, perlu diteliti peningkatan daya saing dodol nanas Si-Jank melalui strategi pemasaran produk dodol nanas Si-Jank. Analisis data dilakukan dengan mengidentifikasi faktor-faktor internal dan faktor-faktor eksternal dalam meningkatkan daya saing dodol nanas Si-Jank, analisis SWOT serta analisis QSPM. Berdasarkan analisis yang diperoleh, maka : Strategi dalam meningkatkan daya saing dodol nanas Si-Jank pada pemasaran produk di Desa Sijang Kecamatan Galing Kabupaten Sambas, yaitu : 1. membuat desain kemasan yang menarik daya beli konsumen; 2. melengkapi perizinan produksi dodol nanas; dan 3. memilih media promosi yang sesuai.
\end{abstract}

Kata Kunci : analisis SWOT, dodol nanas, daya saing, strategi pemasaran, QSPM

Abstract : Dodol is a type of traditional snack that is widely found in various regions in Indonesia. One of the SME businesses in Sijang Village, Galing District, Sambas Regency that processes pineapple into pineapple dodol is Mawar Merah UKM with the Si-Jank pineapple dodol brand. Considering that the Si-Jank pineapple dodol production business from the Mawar Merah UKM has only been carried out since 2018, this pineapple dodol processing business provides a bright opportunity to be developed. However, the sales results of Si-Jank pineapple lunkhead have not been maximized, so the sales target and expected profit have not been achieved, as well as a decline in sales during the Covid-19 pandemic. The right marketing of Si-Jank pineapple lunkhead is very important for the success of this business. SiJank pineapple dodol is influenced by internal factors (strengths and weaknesses) and external (opportunities and threats) as well as the right strategy in marketing Si-Jank pineapple dodol. Therefore, it is necessary to increase the competitiveness of Si-Jank pineapple dodol through the marketing strategy of Si-Jank pineapple dodol products. Data analysis was carried out by identifying internal and external factors in increasing the competitiveness of Si-Jank pineapple lunkhead, SWOT analysis and QSPM. Based on the analysis obtained, then: Strategies in increasing the competitiveness of Si-Jank pineapple lunkhead in product marketing in Sijang Village, Galing District, Sambas Regency, namely: 1. Create packaging designs that attract consumer purchasing power; 2. completeness of pineapple lunkhead production permits; and 3. choose the appropriate promotional media.

Keywords: SWOT analysis, pineapple lunkhead, competitiveness, marketing strategy, QSPM 


\section{A. PENDAHULUAN}

Indonesia memiliki komoditas unggulan di bidang peranian. Komoditas hasil pertanian ini dapat dijadikan sebagai peluang usaha untuk meningkatkan nilai guna dari suatu produk hasil pertanian. Kegiatan ini dilakukan dengan cara mengolah produk pertanian tersebut menjadi beraneka ragam jenis produk pangan termasuk produk makanan ringan. Adapun jenis produk makanan ringan yang beredar dipasaran terdiri dari makanan ringan modern seperti biskuit, wafer, snack, berbagai olahan cokelat dan permen. Selain makanan ringan modern, ada juga makanan ringan tradisional yang banyak ditemui pada berbagai daerah yang ada di Indonesia, seperti dodol. Dodol dikenal sebagai makanan khas suatu daerah yang ada di Indonesia. Oleh karena itu, dodol dikenal dengan nama yang berbeda-beda pada setiap daerah di Indonesia. Sebagai contoh, di Pulau Jawa, dodol dikenal dengan istilah jenang, wingko, wajik, krasikan, angling, dan dodol Garut. Dodol merupakan jenis makanan ringan semi basah. Menurut Setiavani, dkk. (2018), Ada dua jenis dodol yaitu dodol yang terbuat dari beras ketan dan dodol yang terbuat dari buah-buahan. Dodol dari tepung beras ketan putih merupakan yang banyak ditemui. Pada saat ini, produsen dodol sudah banyak menganekaragamkan jenis dodol dengan menambahkan bahan baku yang berasal dari buah-buahan, sehingga dikenal dengan dodol sirsak, dodol nanas, dodol mangga, dodol pepaya, maupun dodol kacang hijau.

Salah satu usaha UKM yang melakukan pengolahan nanas menjadi dodol nanas di Kecamatan Galing adalah UKM Mawar Merah. UKM ini berada di Desa Sijang, Kecamatan Galing, Kabupaten Sambas. Daerah ini, banyak memproduksi buah nanas, sehingga harga jual nanas rendah dan kadang kala buah nanas tidak bisa dikonsumsi dalam bentuk segar lagi karena sudah busuk. Oleh karena itu, dibentuklah UKM Mawar Merah pada tanggal 17 Nopember 2018 dan diketuai oleh Ibu Rita dan memiliki 8 orang anggota. Kegiatan UKM ini adalah memproduksi dodol nanas yang berasal dari daging nanas. Produk dodol nanas dari UKM Mawar Merah ini diberi merek Dodol Nanas Si-Jank. Produksi dodol nanas dalam satu bulan sebanyak $200 \mathrm{~kg}$, di mana harga jual $1 \mathrm{~kg}$ dodol nanas adalah $\mathrm{Rp} 70.000$, dan harga jual kemasan isi 20 pcs seharga Rp 10.000. Masa kadaluarsa dodol nanas ini maksimal 3 bulan setelah produksi. Mengingat usaha produksi dodol nanas Si-Jank dari UKM Mawar Merah ini baru dilakukan, maka usaha pengolahan dodol nanas ini memberikan peluang yang cerah untuk dikembangkan.

Dodol nanas Si-Jank sudah dipasarkan ke toko-toko yang ada di Desa Sijang dan sekitarnya, Kecamatan Sambas, Kota Singkawang, dan Kota Pontianak. Namun, hasil penjualan dodol nanas Si-Jank belum maksimal. Hal ini diikuti dengan menurunnya penjualan selama pandemic Covid-19, sehingga belum tercapainya target penjualan maupun keuntungan yang diharapkan. Pemasaran dodol nanas Si-Jank yang tepat sangat berperan penting guna keberhasilan usaha ini. Pemasaran dodol nanas Si-Jank ini dipengaruhi oleh faktor-faktor internal (kekuatan dan kelemahan) dan eksternal (peluang dan ancaman). Oleh karena itu, perlu diteliti mengenai Peningkatan Daya Saing Dodol Nanas Si-Jank melalui Strategi Pemasaran Produk, guna meningkatkan nilai produk, meningkatkan volume penjualan dari nanas dan dapat meningkatkan pendapatan bagi UKM Mawar Merah ini. Hal ini sesuai dengan pendapat Fandy (2008), bahwa strategi merupakan cara untuk mencapai tujuan jangka panjang. Strategi dalam bisnis dapat berupa peluang geografis, diversifikasi, pengembangan produk, maupun pemasaran produk. Adapun permasalahan dari peneltian ini yaitu :

1. Apa faktor-faktor internal dalam meningkatkan daya saing dodol nanas Si-Jank pada pemasaran dodol nanas Si-Jank di Desa Sijang Kecamatan Galing Kabupaten Sambas?

2. Apa faktor-faktor eksternal dalam meningkatkan daya saing dodol nanas Si-Jank pada pemasaran dodol nanas Si-Jank di Desa Sijang Kecamatan Galing Kabupaten Sambas?

3. Bagaimana strategi dalam meningkatkan daya saing dodol nanas Si-Jank pada pemasaran produk di Desa Sijang Kecamatan Galing Kabupaten Sambas?

Selain itu, tujuan dari penelitian ini adalah :

1. Faktor-faktor internal dalam meningkatkan daya saing dodol nanas Si-Jank pada pemasaran dodol nanas Si-Jank di Desa Sijang Kecamatan Galing Kabupaten Sambas. 
2. Faktor-faktor eksternal dalam meningkatkan daya saing dodol nanas Si-Jank pada pemasaran dodol nanas Si-Jank di Desa Sijang Kecamatan Galing Kabupaten Sambas.

3. Strategi dalam meningkatkan daya saing dodol nanas Si-Jank pada pemasaran produk di Desa Sijang Kecamatan Galing Kabupaten Sambas.

Kontribusi penelitian ini dalam pengembangan ilmu pengetahuan dan teknologi adalah penelitian ini dapat memberikan pengetahuan tentang peningkatan daya saing dodol nanas SiJank melalui strategi pemasaran produk yang tepat. Selain itu, penelitian ini dapat menambah wawasan mahasiswa pada mata kuliah Manajemen Pemasaran.

Berdasarkan hasil penelitian yang pernah dilakukan oleh Hamid (2017) dengan judul Analisis Program Pemasaran Produk UMKM Dodol Garut di Garut. Penelitian ini menggunakan analisis SWOT. Adapun hasil yang diperoleh adalah : 1) Strategi WO : meningkatkan pangsa pasar dengan membidik pasar di luar kota Garut; 2) Strategi WO : Peningkatan kualitas produksi dodol garut; 3) Strategi ST : Menambah kerjasama dengan agen di luar kota Garut; dan 4) Strategi WT: Melaksanakan kegiatan pemasaran, seperti pameran.

\section{B. METODE PENELITIAN}

Metode penelitian yang digunakan adalah metode penelitian deskriptif kuantitatif. Penelitian ini merupakan penelitian studi kasus yang objek penelitiannya adalah dodol nanas Si-Jank yang diproduksi oleh UKM Mawar Merah dan berlokasi di Desa Sijang Kecamatan Galing Kabupaten Sambas. Sumber data yang digunakan adalah data primer dan data sekunder. Di mana data primer diperoleh dari observasi berupa penyebaran kuesioner dan wawancara langsung pada instansi pemerintah yang terkait (Dinas Pertanian dan Disperindagkop), Ketua UKM Mawar Merah, anggota UKM Mawar Merah, dan konsumen dodol nanas Si-Jank. Sedangkan data sekunder diperoleh melalui studi pustaka dengan mengkaji referensi terpilih dan mengumpulkan data dan informasi dari instansi yang terkait dengan bidang kajian penelitian. Selain itu teknik pengumpulan data terdiri dari : wawancara, observasi, dan pencatatan. Populasi dalam penelitian ini adalah seluruh stakeholder yang terkait dalam sistem agribisnis, yaitu Kepala Dinas Pertanian Kabupaten Sambas dan Kepala Disperindagkop Kabupaten Sambas, Ketua UKM Mawar Merah, dan Anggota UKM Mawar Merah sebanyak 8 orang. Metode pengambilan sampel dilakukan secara sengaja (purposive sampling). Adapun teknik analisis data yaitu : identifikasi faktor internal dan faktor ekstrenal; analisis faktor internal dan faktor eksternal; matriks SWOT; analisis matriks SWOT, dan analisis QSPM.

\section{HASIL DAN PEMBAHASAN}

Hasil penelitian mengenai peningkatan daya saing dodol nanas Si-Jank melalui strategi pemasaran produk adalah sebagai berikut :

1. Identifikasi Faktor Internal dan Eksternal

Adapun identifikasi faktor internal dan eksternal dapat dirincikan sebagai berikut :

a. Faktor Internal

Faktor internal terdiri dari dua aspek, yaitu :

1) Kekuatan. Aspek kekuatan dari peningkatan daya saing dodol nanas Si-Jank melalui strategi pemasaran produk yakni : a) Memiliki cita rasa yang enak; b) Produk tidak menggunakan bahan pengawet; c) Diproduksi kontinyu; d) Harga produk terjangkau; d) Memiliki pelanggan atau konsumen tetap; e) Bahan baku mudah diperoleh; dan f) Tenaga kerja terampil.

2) Kelemahan. Aspek kelemahan dari peningkatan daya saing dodol nanas Si-Jank melalui strategi pemasaran produk yakni : a) Produk tidak tahan lama; b) Kemasan sederhana dan informasi pada label belum lengkap; c) Belum ada izin produk; d) Promosi belum luas; dan e) Proses pembuatan dodol masih sederhana.

b. Faktor Eksternal

Faktor eksternal terdiri dari dua aspek, yaitu : 
1) Peluang. Aspek peluang dari peningkatan daya saing dodol nanas Si-Jank melalui strategi pemasaran produk yakni : a) Permintaan pasar cukup tinggi; b) Adanya dukungan pemerintah setempat; dan c) Loyalitas konsumen.

2) Ancaman. Aspek ancaman dari peningkatan daya saing dodol nanas Si-Jank melalui strategi pemasaran produk yakni : a) Adanya produk sejenis; b) Biaya promosi yang tinggi; c) Produk mudah ditiru; d) Adanya makanan ringan/cemilan modern; e) Selera masyarakat yang berubah-ubah; f) Munculnya penjual makanan ringan secara online; dan g) Kondisi ekonomi fluktuatif.

2. Matriks Internal Factor Evaluation (IFE) dan Eksternal Factor Evaluation (EFE)

Hasil identifikasi dari faktor-faktor internal dan eksternal dapat dirincikan sebagai berikut :

a. Matriks Internal Faktor Evaluation (IFE)

Matriks Internal Faktor Evaluation (IFE) dapat dilihat pada Tabel 1.

Tabel 1 Maktriks Internal Faktor Evaluation (IFE)

\begin{tabular}{|c|c|c|c|c|}
\hline \multicolumn{2}{|r|}{ Faktor Internal } & \multirow{2}{*}{ Rating } & \multirow{2}{*}{ Bobot } & \multirow{2}{*}{ Skor } \\
\hline \multicolumn{2}{|c|}{ Kekuatan } & & & \\
\hline 1 & Memiliki cita rasa yang enak & 4 & 0,084 & 0,336 \\
\hline 2 & Produk tidak menggunakan bahan pengawet & 4 & 0,085 & 0,338 \\
\hline 3 & Diproduksi kontinyu & 3 & 0,079 & 0,237 \\
\hline 4 & Harga produk terjangkau & 3 & 0,085 & 0256 \\
\hline 5 & Memiliki pelanggan/konsumen tetap & 3 & 0,085 & 0,254 \\
\hline 6 & Bahan baku mudah diperoleh & 4 & 0,085 & 0,338 \\
\hline 7 & Tenaga kerja terampil & 3 & 0,081 & 0,244 \\
\hline \multicolumn{3}{|c|}{ Jumlah Bobot dan Skor dari Faktor Kekuatan } & $\mathbf{0 , 5 8 3}$ & 2,003 \\
\hline \multicolumn{2}{|c|}{ Kelemahan } & Rating & Bobot & Skor \\
\hline 1 & Produk tidak tahan lama & 4 & 0,079 & 0,316 \\
\hline 2 & $\begin{array}{l}\text { Kemasan sederhana dan informasi pada label belum } \\
\text { lengkap }\end{array}$ & 4 & 0,086 & 0,344 \\
\hline 3 & Belum ada izin produksi & 3 & 0,088 & 0,263 \\
\hline 4 & Promosi belum luas & 3 & 0,086 & 0,258 \\
\hline 5 & Proses pembuatan masih sederhana dan manual & 3 & 0,078 & 0,234 \\
\hline \multicolumn{3}{|c|}{ Jumlah Bobot dan Skor dari Faktor Kelemahan } & 0,417 & 1,415 \\
\hline \multicolumn{3}{|c|}{ Jumlah Bobot Faktor Internal } & $\mathbf{1 , 0 0 0}$ & 3,418 \\
\hline
\end{tabular}

Sumber : Analisis Data Primer, 2020

Berdasarkan analisis matriks IFE pada Tabel 1, jumlah skor yang diperoleh adalah 3,418 . Skor dengan nilai 3,418 menunjukkan bahwa usaha pemasaran dodol nanas SiJank ini berada pada posisi yang kuat. Menurut David (2012), jika skor rata-rata di bawah 2,5 berarti organisasi pada posisi yang lemah secara internal, sedangkan skor rata-rata di atas 2,5 mengindikasikan pada posisi internal yang kuat.

Hasil pembobotan faktor internal yang paling tinggi pada kekuatan adalah produk tidak menggunakan bahan pengawet dengan skor 0,338, dan bahan baku mudah diperoleh dengan skor 0,338 . Hasil pembobotan faktor internal yang paling tinggi pada kelemahan adalah kemasan sederhana dan informasi pada label belum lengkap, dengan skor 0,344. Walaupun demikian, permintaan konsumen akan dodol nanas Si-Jank semakin meningkat, karena dodol nanas Si-Jank ini memiliki konsumen tetap dan konsumen tidak tetap. Namun, produksi dari dodol nanas Si-Jank ini belum mencukupi permintaan masyarakat. 
b. Matriks Eksternal Faktor Evaluation (EFE)

Maktriks Eksternal Faktor Evaluation (EFE) dapat dilihat pada Tabel 2.

Tabel 2 Maktriks Eksternal Faktor Evaluation (EFE)

\begin{tabular}{clccc}
\hline \multicolumn{1}{c}{ Faktor Eksternal } & \multirow{2}{*}{ Rating } & Bobot & \multirow{2}{*}{ Skor } \\
\hline Peluang & & & & \\
\hline 1 & Permintaan pasar cukup tinggi & 4 & 0,139 & 0,556 \\
\hline 2 & Adanya dukungan pemerintah setempat & 4 & 0,138 & 0,552 \\
\hline 3 & Loyalitas konsumen & 4 & 0,137 & 0,548 \\
\hline \multicolumn{1}{c}{ Jumlah Bobot dan Skor dari Faktor Peluang } & $\mathbf{0 , 4 1 4}$ & $\mathbf{1 , 6 5 7}$ \\
\hline Ancaman & & Rating & Bobot & Skor \\
\hline 1 & Adanya produk sejenis & 2 & 0,080 & 0,161 \\
\hline 2 & Biaya promosi yang tinggi & 3 & 0,078 & 0,235 \\
\hline 3 & Produk mudah ditiru & 2 & 0,089 & 0,177 \\
\hline 4 & Adanya makanan ringan/cemilan modern & 2 & 0,089 & 0,177 \\
\hline 5 & Selera masyarakat berubah-ubah & 2 & 0,081 & 0,163 \\
\hline 6 & Munculnya penjual makanan ringan secara online & 4 & 0,081 & 0,325 \\
\hline 7 & Kondisi ekonomi fluktuatif & 4 & 0,088 & 0,350 \\
\hline & & Jumlah Bobot dan Skor dari Faktor Ancaman & $\mathbf{0 , 5 8 6}$ & $\mathbf{1 , 5 8 7}$ \\
\hline & & Jumlah Bobot Faktor Eksternal & $\mathbf{1 , 0 0 0}$ & $\mathbf{3 , 2 4 4}$ \\
\hline
\end{tabular}

Sumber : Analisis Data Primer, 2020

Berdasarkan analisis matriks EFE pada Tabel 2, jumlah skor yang diperoleh adalah 3,244 . Skor dengan nilai 3,244 ini menunjukkan bahwa usaha pemasaran dodol nanas Si-Jank ini berada pada posisi yang kuat. Hasil pembobotan faktor eksternal yang paling tinggi pada peluang adalah permintaan pasar yang cukup tinggi dengan skor 0,556. Dodol nanas Si-Jank banyak digemari oleh masyarakat karena cita rasanya yamg enak dan teskturnya yang gurih. Namun, jumlah tenaga kerja yang masih sedikit, sehingga produksi dodol nanas Si-Jank masih belum mencukupi permintaan pasar, maka peluang pasar dari usaha dodol nanas ini masih besar.

Sedangkan hasil pembobotan faktor eksternal yang paling tinggi pada ancaman adalah kondisi ekonomi yang fluktuatif, dengan skor 0,350. Pendapatan akan mempengaruhi daya beli terhadap dodol nanas Si-Jank. Hal ini ditunjukkan pada kondisi ekonomi selama pandemik covid-19 yang terjadi pada awal bulan Maret tahun 2020. Kondisi ekonomi ini mempengaruhi produksi dan penjualan dodol nanas Si-Jank. Sejak adanya pandemik covid-19 pada awal bulan Maret tahun 2020, maka UKM Mawar Merah sulit mendapatkan bahan baku dan bahan penunjang untuk proses produksi. Selain itu, pendistribusian dodol nanas Si-Jank hingga sampai ke tangan konsumen terhambat. Hal ini dikarenakan hampir seluruh kegiatan perekonomian di Indonesia maupun di dunia dikurangi atau dihentikan untuk sementara waktu selama adanya pandemic Covid-19 ini di mana hal ini bertujuan untuk mengurangi penyebaran virus Covid-19. Namun, kegiatan produksi ini dikurangi atau dihentikan selama 3 bulan. Pada awal bulan Juni tahun 2020, semua kegiatan perekonomian mulai beroperasi lagi, guna memenuhi kebutuhan manusia yang beraneka ragam dengan mengikuti aturan protokol kesehatan selama pandemik Covid-19.

\section{Strategi Pemasaran Dodol Nanas Si-Jank}

Matriks SWOT ini menggunakan hasil analisis yang diperoleh dari matriks IFE dan EFE.

Berdasarkan Matriks SWOT, maka diperoleh 15 alternatif strategi yang akan digunakan

UKM Mawar Merah pada pemasaran dodol nanas Si-Jank, yaitu: 
a. Strategi Strength-Opportunity (SO)

Adapun alternatif strategi SO yang dapat dirumuskan yaitu : 1) Memanfaatkan keterampilan tenaga kerja dan pelatihan dari pemerintah setempat guna pengembangan usaha dodol nanas, baik produksi dodol nanas maupun sebagai pusat pelatihan dodol nanas; 2) Aktif pada kegiatan pelatihan, pembinaan, dan pendampingan dari pemerintah setempat agar usaha dodol semakin berkembang dan keterampilan tenaga kerja semakin bertambah; 3) Memperluas area pemasaran dodol nanas; dan 4) Adanya peramalan produksi dan penjualan

b. Strategi Weakness-Opportunity (WO)

Strategi WO yang dapat dirumuskan adalah : 1) Melakukan uji mutu dan uji daya simpan produk; 2) Membuat desain kemasan yang menarik daya beli konsumen dan informasi pada label lebih lengkap; 3) Melengkapi perizinan produksi dodol nanas; dan 4) Memanfaatkan pelatihan dari pemerintah sebagai tempat media sharing dalam usaha peningkatan pemasaran dodol nanas dan dapat dijadikan sebagai produk oleh-oleh khas Sambas.

c. Strategi Strength-Threat (ST)

Strategi ST yang dapat dirumuskan yaitu : 1) Meningkatkan jumlah produksi (kuantitas) dan menjaga mutu (kualitas) dodol nanas; 2) Menggunakan kemasan yang menarik dan unik; 3) Menambah varian rasa dari dodol nanas; dan 4) Mempunyai kemasan dengan berbagai berat netto agar konsumen bisa membeli dodol nanas.

d. Strategi Weakness- Threat (WT)

Strategi WT yang dapat dirumuskan adalah : 1) Mempertahankan kualitas dodol nanas; 2) Memilih media promosi yang sesuai; dan 3) Menggunakan teknologi dalam proses produksi.

\section{Analisis Matriks SWOT}

Menurut Rangkuti (2014), Analisis SWOT ini merupakan suatu cara untuk mengidentifikasikan berbagai faktor secara sistematis dalam rangka merumuskan strategi suatu perusahaan. Analisis ini didasarkan pada logika dapat memaksimalkan kekuatan (Strengths) dan peluang (Opportunities), namun secara bersamaan dapat meminimalkan kelemahan (Weaknesses) dan ancaman (Threats). Analisis matriks SWOT menghasilkan perhitungan sumbu $X$ (pengurangan antara sub total kekuatan dan kelemahan) dengan nilai 0,588 dan perhitungan sumbu $Y$ (pengurangan sub total peluang dan ancaman) adalah 0,070. Berdasarkan analisis tersebut, maka posisi UKM Mawar Merah dalam memasarkan dodol nanas Si-Jank dapat dilihat pada Gambar 1.

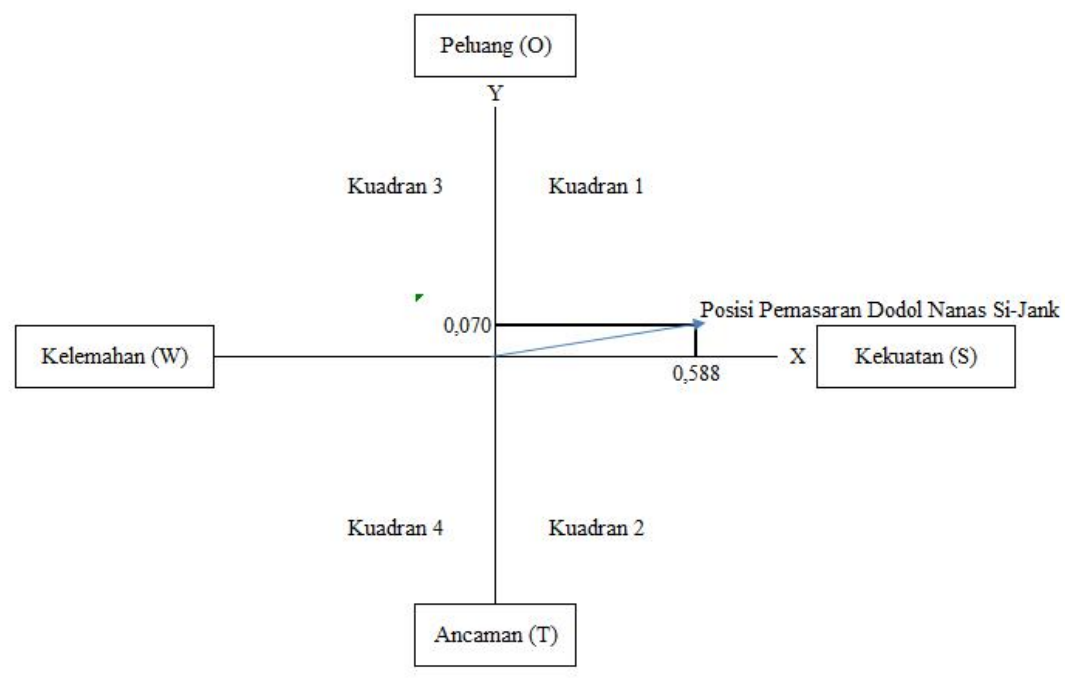

Gambar 1 Analisis SWOT dari Pemasan Dodol Nanas Si-Jank 
Berdasarkan Gambar 1, menunjukkan bahwa posisi UKM Mawar Merah dalam pemasaran dodol nanas Si-Jank berada pada Kuadran 1. Strategi yang digunakan UKM Mawar Merah dalam pemasaran dodol nanas Si-Jank adalah strategi SO (Strengths-Opportunities). Adapun kekuatan pada produk dodol nanas Si-Jank yaitu :

a. Memanfaatkan keterampilan tenaga kerja dan pelatihan dari pemerintah setempat guna pengembangan usaha dodol nanas, baik produksi dodol nanas maupun sebagai pusat pelatihan dodol nanas.

b. Aktif pada kegiatan pelatihan, pembinaan, dan pendampingan dari pemerintah setempat agar usaha dodol semakin berkembang dan keterampilan tenaga kerja semakin bertambah.

c. Memperluas area pemasaran dodol nanas.

d. Adanya peramalan produksi dan penjualan.

Strategi menggunakan faktor internal di mana dodol nanas Si-Jank dapat diproduksi secara kontinyu dan dapat memenuhi permintaan konsumen. Pemasaran dodol nanas Si-Jank dapat menggunakan kekuatan untuk memanfaakan peluang sebaik mungkin agar tujuan dari pemasaran dodol nanas Si-Jank dapat tercapai dengan sesuai tujuan.

\section{QSPM}

Adapun alternatif strategi yang dipilih oleh ketua UKM Mawar Merah dalam pemasaran dodol nanas Si-Jank yaitu : a) Membuat desain kemasan yang dapat menarik daya beli konsumen; b) Melengkapi perizinan produksi dodol nanas; dan c) Memilih media promosi yang sesuai.

Alat analisis yang digunakan pada tahap pengambilan keputusan untuk menentukan prioritas strategi adalah Matriks Perencanaan Strategi Kuantitatif (Quantitative Strategic Planning Matrix atau QSPM). Adapun hasil analisis matriks QSPM dapat dilihat pada Tabel 3.

Tabel 3 Analisis Matriks QSPM

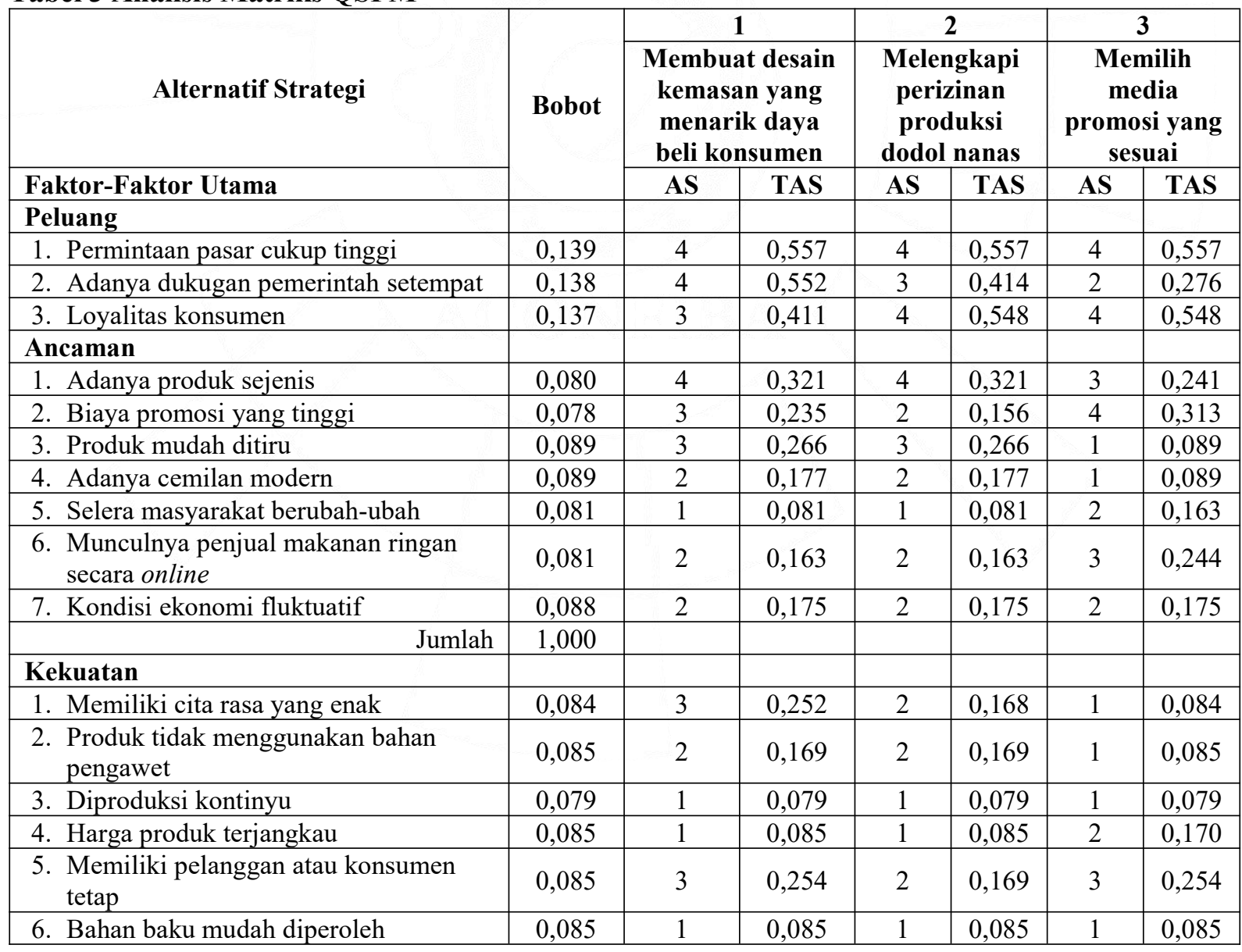




\begin{tabular}{|c|c|c|c|c|c|c|c|}
\hline 7. Tenaga kerja terampil & 0,081 & 1 & 0,081 & 1 & 0,081 & 1 & 0,081 \\
\hline \multicolumn{8}{|l|}{ Kelemahan } \\
\hline 1. Produk tidak tahan lama & 0,079 & 1 & 0,079 & 2 & 0,158 & 1 & 0,079 \\
\hline 2. Kemasan sederhana & 0,086 & 4 & 0,344 & 2 & 0,172 & 2 & 0,172 \\
\hline 3. Belum ada izin produksi & 0,088 & 2 & 0,175 & 4 & 0,351 & 2 & 0,175 \\
\hline 4. Promosi belum luas & 0,086 & 3 & 0,258 & 2 & 0,172 & 4 & 0,344 \\
\hline $\begin{array}{l}\text { 5. Proses pembuatan masih sederhana } \\
\text { dan manual }\end{array}$ & 0,078 & 1 & 0,078 & 1 & 0,078 & 1 & 0,078 \\
\hline Jumlah & $\mathbf{1 , 0 0 0}$ & & 4,877 & & 4,626 & & 4,379 \\
\hline
\end{tabular}

Sumber : Analisis Data Primer, 2020

Berdasarkan hasil analisis matriks QSPM pada Tabel 3, maka diperoleh prioritas strategi pemasaran dodol nanas Si-Jank sebagai berikut :

1. Membuat desain kemasan yang menarik daya beli konsumen dengan jumlah TAS (Sum Total Attrativeness Scores/STAS) sebesar 4,877.

2. Melengkapi perizinan produksi dodol nanas dengan jumlah TAS (Sum Total Attrativeness Scores/STAS) sebesar 4,626.

3. Memilih media promosi yang sesuai dengan jumlah TAS (Sum Total Attrativeness Scores/STAS) sebesar 4,379.

\section{PENUTUP}

1. Kesimpulan

Kesimpulan dari penelitian mengenai Peningkatan Daya Saing Dodol Nanas Si-Jank melalui Strategi Pemasaran Produk yaitu :

a. Faktor-faktor internal (kekuatan dan kelemahan) dalam meningkatkan daya saing dodol nanas Si-Jank pada pemasaran dodol nanas Si-Jank di Desa Sijang Kecamatan Galing Kabupaten Sambas yaitu : 1) Memiliki cita rasa yang enak; 2) Produk tidak menggunakan bahan pengawet; 3) Diproduksi kontinyu; 4) Harga produk terjangkau; 5) Memiliki pelanggan atau konsumen tetap; 6) Bahan baku mudah diperoleh; 7) Tenaga kerja terampil; 8) Produk tidak tahan lama; 9) Kemasan sederhana dan informasi pada label belum lengkap; 10) Belum ada izin produksi; 11) Promosi belum luas; dan 12) Proses pembuatan dodol masih sederhana.

b. Faktor-faktor eksternal (peluang dan ancaman) dalam meningkatkan daya saing dodol nanas Si-Jank pada pemasaran dodol nanas Si-Jank di Desa Sijang Kecamatan Galing Kabupaten Sambas yaitu : 1) Permintaan pasar cukup tinggi; 2) Adanya dukungan pemerintah setempat; 3) Loyalitas konsumen; 4) Adanya produk sejenis; 5) Biaya promosi yang tinggi; 6) Produk mudah ditiru; 7) Adanya makanan ringan atau cemilan modern; 8) Selera masyarakat yang berubah-ubah; 9) Munculnya penjual makanan ringan secara online; dan 10) Kondisi ekonomi fluktuatif.

c. Strategi dalam meningkatkan daya saing dodol nanas Si-Jank pada pemasaran produk di Desa Sijang Kecamatan Galing Kabupaten Sambas, yaitu : 1) Membuat desain kemasan yang menarik daya beli konsumen; 2) Melengkapi perizinan produksi dodol nanas Si-Jank; dan 3) Memilih media promosi yang sesuai.

2. Saran

Adapun saran dari penelitian mengenai Peningkatan Daya Saing Dodol Nanas Si-Jank melalui Strategi Pemasaran Produk yaitu :

a. Diperlukan adanya sosialisasi mengenai arti penting kemasan dalam pemasaran produk.

b. Perlu dilakukan sosialisasi dan pendampingan dalam proses perizinan produksi.

c. Diperlukan adanya sosialisasi dan workshop promosi produk baik pada media cetak maupun media elektronik. 


\section{E. DAFTAR PUSTAKA}

David, F.R. (2012). Manajemen Strategis Konsep (Edisi 12). Jakarta : Salemba Empat.

Fandy, Tjiptono. (2008). Strategi Pemasaran. Yogyakarta.

Hamid, Satim. (2017). Analisis Program Pemasaran Produk UMKM Dodol Garut. Bekasi : STIE Pertiwi Bekasi.

Rangkuti, Freddy. (2014). Analisis SWOT Teknik Membedah Kasus Bisnis. Jakarta: PT. Gramedia Pustaka Utama.

Setiavani, Gusti, dkk. (2018). Teknologi Pengolahan dan Peningkatan Nilai Gizi Dodol. Bogor : Departemen Ilmu Pangan dan Teknologi Pangan Fakultas Teknologi Pertanian Institut Pertanian Bogor. 